\title{
ARTE E MEMÓRIA: DA CRIAÇÃO ARTÍSTICA À FORMAÇÃO DOS SENTIDOS ESTÉTICOS
}

\author{
ARTE Y MEMORIA: DE LA CREACIÓN ARTÍSTICA A LA FORMACIÓN \\ DE LOS SENTIDOS ESTÉTICOS
}

\author{
Isis Conrado Haun \\ Universidade Estadual do Sudoeste da Bahia - UESB
}

\begin{abstract}
Resumo
O objetivo deste estudo é analisar de que forma a memória, a imaginação e a criatividade se relacionam possibilitando o processo de criação artística tomando como referência a psicologia histórico-cultural. Inicialmente discutimos a memória enquanto função psíquica a partir dos postulados da Escola de Vigotski se manifestando também como um fenômeno histórico social. Analisamos como as experiências humanas e a memória servem de base para a imaginação e a criatividade no processo de criação artística. Por fim, discutimos a arte enquanto expressão da memória situada no contexto da prática social e a formação dos sentidos estéticos para o desenvolvimento pessoal.
\end{abstract}

Palavras-chave: Arte. Memória. Psicologia histórico-cultural.

\section{Resumen}

El objetivo de este estudio es analizar de qué forma la memoria, la imaginación y la creatividad se relacionan posibilitando el proceso de creación artística tomando como referencia la psicología histórico-cultural. Inicialmente discutimos la memoria como función psíquica a partir de los postulados de la Escuela de Vigotski manifestándose también como un fenómeno histórico social. Analizamos cómo las experiencias humanas y la memoria sirven de base para la imaginación y la creatividad en el proceso de creación artística. Por último, discutimos el arte como expresión de la memoria situada en el contexto de la práctica social y la formación de los sentidos estéticos para el desarrollo personal.

Palabras claves: Arte. Memoria. Psicología histórico-cultural. 


\section{Introdução}

O presente texto tem por objeto de estudo a relação arte e memória, tomando como referência obras elaboradas por Vigotski, Luria e Leontiev, integrantes de um coletivo de pesquisas que produziram a psicologia histórico-cultural, também conhecida com Escola de Vigotski.

Esses autores empreenderam uma revisão crítica dos principais sistemas psicológicos de sua época, suas determinações histórico-sociais, seus limites e suas possibilidades. Eles defenderam que o estudo do desenvolvimento social do psiquismo humano fosse o verdadeiro objeto da psicologia científica.

A partir das produções da psicologia histórico-cultural é possível correlacionar fenômenos psíquicos com o mundo material, sendo assim, é possível também traçar uma proposta de estudo da memória como função psíquica relacionada ao movimento histórico da realidade, o que nos permite também, entender a memória como um fenômeno históricosocial e a sua relação com a arte.

A psicologia histórico-cultural entende o homem como um produto de seus próprios atos e que se desenvolve historicamente. Deste modo, se interessou pelo funcionamento cognitivo do ser humano, enquanto parte de sua realidade histórico-cultural específica, cujo pressuposto era o de que o homem é um ser de natureza social.

Assim, sem perder de vista a unidade contraditória entre as dimensões natural e social, Vigotski e seus colaboradores consideraram que o desenvolvimento do psiquismo humano e suas funções não resultam apenas de uma complexificação natural, evolutiva e biológica, mas da própria natureza social.

A memória, assim como outras funções psíquicas (atenção, sensação, percepção, emoção, sentimento, criatividade, imaginação, linguagem, pensamento), foi objeto desses estudiosos visando à compreensão do desenvolvimento da totalidade da psique humana. Importante salientar que as funções psíquicas não se desenvolvem de forma isolada, mas num sistema interfuncional onde uma depende da outra e se relacionam entre si para se desenvolverem.

Ao passo que buscamos entender a memória enquanto função psíquica, buscamos situála como um importante elemento para a construção do conhecimento, dentre eles o artístico. 


\section{ARTE E MEMÓRIA: DA CRIAÇÃo ARTÍSTICA À FORMAÇÃo DOS SENTIDOS ESTÉTICOS}

Por isso, tratamos também da arte como uma forma de expressão da memória do gênero humano.

A arte é resultado das experiências humanas, da memória, da criatividade e da imaginação e o processo de produção artística envolve a apropriação da realidade concreta. A arte, como reflexo de uma parcela do mundo humano, presentifica o que se produziu em épocas diferentes e espaços distintos imortalizando memórias.

A função essencial da arte é ampliar e enriquecer a realidade cultural da humanidade e possibilita ao homem compreender esta mesma realidade de forma mais crítica. Através dela, o homem pode afirmar sua essência e se reconhecer no mundo objetivo criado por ele.

Diante do exposto, o objetivo deste estudo é analisar de que forma a memória, a imaginação e a criatividade se relacionam possibilitando o processo de criação da arte tomando como referência a psicologia histórico-cultural, bem como discutir a arte enquanto expressão da memória situada no contexto da prática social e a formação dos sentidos estéticos para o desenvolvimento pessoal.

\section{A concepção de memória a partir da psicologia histórico-cultural}

Entender uma perspectiva histórico-cultural da memória não se resume em compreender aspectos fisiológicos dessa função psíquica limitando-a apenas a uma manifestação de assembleias neurais localizadas no cérebro. Cabe ressaltar que os pesquisadores da Escola de Vigotski não julgaram de menor valor a compreensão biológica e as bases neurofisiológicas da memória, mas tiveram o mérito de demonstrar a sua complexidade e o seu desenvolvimento cultural.

De acordo com Martins (2013, p.60) “a memória é, pois, um processo complexo e ativo cujo desenvolvimento, filo e ontogenético, compreende a superação de formas naturais, involuntárias, em direção a formas voluntárias, culturalmente desenvolvidas".

Coube a Vigotski o mérito do primeiro estudo sistemático das formas superiores de memória na criança. Vigotski, com a colaboração de seus alunos Leontiev e Zamkov:

mostrou que as formas superiores de memória constituem uma forma complexa de atividade psíquica social por origem e mediata por estrutura e estudou as etapas fundamentais de desenvolvimento da memorização mediata mais complexa (LURIA, 1999, p.42). 
Martins (2013) afirma que ao nível animal a função psíquica circunscreve-se pelas constituições biológicas fixadas por fatores hereditários. Ao passo que para o homem, essas formações não são determinadas pela hereditariedade, elas aparecem no transcurso da vida como resultado de apropriações sucessivas e efetivadas pela atividade que o vincula ao mundo social.

Vigotski tornou o problema do desenvolvimento das formas superiores de memória, pela primeira vez, objeto de um estudo especial. A Psicologia passa a estudar a maneira pela qual se registram os vestígios, os mecanismos fisiológicos desse registro, as condições que contribuem para ele, os seus limites e os procedimentos que permitem ampliar o volume do material registrado. Todo o reforço dos conhecimentos e habilidades e a capacidade de aproveitá-los.

Em virtude disso, impõe-se à Psicologia uma série de problemas complexos, que fazem parte da área de estudos dos processos da memória. Ela se propõe responder uma série de questões que envolvem os processos mnemônicos, tais como a duração dos vestígios, mecanismos e mudanças que podem interferir na conservação desses vestígios da memória e qual a influência que eles podem exercer no psiquismo humano.

Mas, como definir a memória à luz da psicologia histórico-cultural?

Segundo Luria (1999, p.39),

entendemos por memória o registro, a conservação e a reprodução dos vestígios da experiência anterior, registro esse que dá ao homem a possibilidade de acumular informação e operar com os vestígios da experiência anterior após o desaparecimento dos fenômenos que provocaram tais vestígios.

Então, quando falamos em memória, falamos em registro de experiências humanas que foram atentadas, sentidas, percebidas por indivíduos ou grupos, que estão determinadas pelos contraditórios processos históricos. Registros fundamentais que possibilitam a formação de uma imagem por evocação para que não se percam no tempo e permitem a ativação do sistema psíquico humano.

Por isso não é possível entender a memória como algo isolado. Ela move todo um sistema psíquico. Os fenômenos da memória se inter-relacionam com outras funções 


\section{ARTE E MEMÓRIA: DA CRIAÇÃO ARTÍSTICA À FORMAÇÃO DOS SENTIDOS ESTÉTICOS}

psíquicas e podem até pertencer igualmente ao campo das emoções, da atenção e ao campo das percepções.

Vigotski e Luria (1996) discorrem sobre o processo de transição das formas naturais de memória para as formas culturais e afirmam que diferentemente do animal, as funções psíquicas não são determinadas pela hereditariedade, elas aparecem no transcurso da vida como resultado de apropriações sucessivas e efetivadas pela atividade que o vincula ao mundo social. O que leva Martins (2013) afirmar que a memória é um processo complexo e ativo cujo desenvolvimento compreende a superação de formas naturais, involuntárias, em direção a formas voluntárias, culturalmente desenvolvidas.

Partindo desse pressuposto é possível afirmar que no decorrer de seu desenvolvimento a memória é treinada e vai mudando para novos sistemas e novas técnicas de rememoração. Evoluem de formas simples de memorização imediata para formas mais elaboradas com a utilização funcional de signos auxiliares.

Esses signos externos criam condições de ambiente social e de desenvolvimento cultural, que possibilitam entender os métodos e recursos utilizados pelos homens que ajudam a memória. Com isso, Vigotski e Luria (1996) ressaltam a importância dos signos na constituição da memória afirmando que a verdadeira essência da memória humana está no fato de os seres humanos serem capazes de lembrar ativamente com a ajuda de signos.

Assim, fica claro a importância do signo como mediação social da realidade com o nosso psiquismo e da relação dos signos com as palavras e com a memória. O que nos leva a pensar sobre a possibilidade de controle da memória nas formas de produção humana e nas estratégias de organização das imagens, da imaginação e do desenvolvimento do psiquismo humano.

Dessa forma, aprender culturalmente as formas de entender, decifrar e dominar a utilização desses signos é de extrema importância para o desenvolvimento cultural da memória e consequentemente para o desenvolvimento das produções humanas que são criadas a partir de elementos registrados.

A memória confere sentido às experiências vividas no passado possibilitando serem ressignificadas no presente. Assim, a memória pode ser encarada não somente como uma ferramenta de guardar dados mnemônicos, mas, sobretudo, como uma ferramenta essencial para a elaboração do conhecimento científico, filosófico, artístico e técnico e permite alcançar novos saberes e práticas.

\begin{tabular}{l|l} 
Revista RBBA & Revista Binacional Brasil Argentina
\end{tabular} 
Por isso a importância da memória, pois possibilita perpetuar informações, conhecimentos e experiências às futuras gerações e permite a humanidade se colocar em constante processo de evolução e de tomada de consciência acerca de suas produções. Pode-se dizer que sem a memória seria impossível à apropriação dos resultados da prática social anteriormente concretizada.

Enfim, a reprodução dos vestígios da memória que em certas condições podem tornar-se objeto da atividade consciente, podem se tornar conhecimentos que são acumulados e compartilhados entre grupos humanos possibilitando formação de uma memória social. Com isso, é possível afirmar que os vestígios da memória associados a outras funções psíquicas podem se transformar em arte.

\section{Memória, imaginação e criatividade no processo de criação artística}

O processo de criação se refere à infinita capacidade humana para a associação e circulação de experiências e ideias. Ou seja, para criar algo novo, os indivíduos precisam se apoderar das experiências humanas. A partir de tal afirmativa vamos traçar algumas relações que envolvem as experiências humanas, a memória e a arte e discutir o processo de criação artística mediada pelas funções psíquicas.

Fischer (1973, p.14) aponta que "para conseguir ser um artista, é necessário dominar, controlar e transformar a experiência em memória, a memória em expressão, a matéria em forma". E complementa dizendo que um artista só pode exprimir experiência, tornando-a arte, daquilo que seu tempo e as condições sociais têm a oferecer.

Nesse entendimento, a arte não só precisa derivar de uma intensa experiência da realidade como precisa ser construída e tomar forma através da objetividade e do trabalho. $\mathrm{O}$ trabalho para um artista é um processo consciente e racional de dominação da natureza que resulta numa obra de arte. Assim, a emoção para um artista não é tudo; ele precisa também saber tratá-la, transmiti-la através do conhecimento de regras, técnicas e recursos.

Por si só, nem o mais sincero sentimento é capaz de criar arte. Para tanto não lhe falta apenas técnica e maestria, porque nem o sentimento expresso em técnica jamais consegue produzir uma obra lírica ou uma sinfonia; para ambas as coisas se faz necessário ainda o ato criador de superação desse 


\section{ARTE E MEMÓRIA: DA CRIAÇÃO ARTÍSTICA À FORMAÇÃO DOS SENTIDOS ESTÉTICOS}

sentimento, da sua solução, da vitória sobre ele, e só então esse ato aparece, só então a arte se realiza. Eis por que a percepção da arte também exige criação, porque para essa percepção não basta simplesmente vivenciar com sinceridade o sentimento que dominou o autor, não basta entender da estrutura própria da arte: é necessário ainda superar criativamente o seu próprio sentimento, encontrar a sua cartase, só então o efeito da arte se manifestará em sua plenitude (VIGOTSKI, 1999, p.314).

Segundo Vigotski (2014) as percepções externas e internas são o fundamento da nossa experiência e o ponto de apoio para a criatividade e para criação artística. Esses traços das impressões exteriores não se armazenam de modo imóvel no nosso cérebro, possuem um grau de mobilidade, se transformam e se reelaboram.

Os artistas criam com base no seu contato sensível com o mundo. Às vezes são temas ligados à sua vida pessoal, lembranças, experiências, ideias, memórias, sentimentos, intenções, emoções e sensações vividas e experienciadas. Sendo assim, a criação apoia-se na memória, ou seja, nossa imaginação modifica e reelabora elementos retirados da própria realidade, gerando uma nova combinação de tais elementos.

A memória tem uma relação muito próxima com as outras funções psíquicas. O que nos leva a afirmar que o homem capta a realidade e dela se apropria com todos os seus sentidos. As percepções trazidas pelos cinco sentidos são transformadas em imagens que se tornam o material da faculdade intelectual.

A memória cria as imagens que servem de arcabouço para a imaginação e a criatividade e possibilitam o trabalho dos processos mais elevados do pensamento. E ao colocar o pensamento em movimento, impulsiona a atividade criadora. Dessa forma, a faculdade intelectual atua sobre as imagens nela armazenadas a partir da percepção sensorial.

O processo de criação artística é um processo de registro. Registrar, nesse sentido, é dar visibilidade aos produtos da mente humana sendo possível reconhecer-se e compreender-se sujeito da historia e da memória. É se ver capaz de se expressar nas mais variadas linguagens e construir um entendimento que possa ser compartilhado.

Aquele que registra torna-se sujeito da linguagem, isto é, o que produz e cria, o artista. Este necessita atentar os seus sentidos para o mundo e aprender a escutar, observar e ver o que passa despercebido no cotidiano, ou mesmo o que se percebe no cotidiano ou na vida nãocotidiana, estabelecendo um permanente dialogo com a imaginação.

Registar é deixar vivas as experiências, por isso, as produções artístico-culturais são janelas abertas ao diálogo com o público contemplador. Tanto o registro artístico, quanto as 
impressões e reflexões sobre ele são importantes. Mais do que isso, são registros singulares de experiências estéticas únicas que serão resignificadas permanentemente quando colocadas na prática social.

O ser humano cria com o alicerce da experiência e de tudo o que ela percebe no mundo em que vive. O produto da imaginação é sempre arquitetado de materiais hauridos da realidade, do acúmulo de experiências vivenciadas anteriormente. A riqueza cultural produzida pela atividade humana é a base de toda e qualquer criação. Portanto, beber da fonte dos grandes modelos é condição inalienável para a rica criação. Somente a partir da apropriação do existente é possível ser verdadeiramente criativo (SACCOMANI, 2014).

A apropriação de conhecimentos historicamente acumulados é então fundamental nesse processo. Quanto maior o acumulo de experiências, conhecimentos e abstrações, maior será o poder de criação. Por isso se fala em ampliar ao máximo as experiências dos indivíduos para poder proporcionar bases suficientemente sólidas para sua atividade criativa.

Nesse sentido, Vigotski (2014, p.12) afirma que:

Se examinarmos a história das grandes realizações e das grandes descobertas, podemos constatar que quase sempre surgiram como resultado da enorme experiência previamente acumulada. Precisamente toda fantasia parte da experiência acumulada: quanto mais rica a experiência, tanto mais deverá ser rica, em circunstâncias semelhantes, a imaginação.

Aqui, Vigotski afirma que a fantasia não se opõe a memória, pelo contrário. Os produtos da imaginação constroem-se a partir desses elementos elaborados e transformados da realidade. A criatividade se apoia nos registros mnemônicos para dispor de novas combinações. São vários fragmentos que podem ser revisitados, reproduzidos, transformados, superados, abandonados, que se unem para a elaboração de novas produções e criações.

Por essa razão, Vigotski (2014) destaca a importância que tem para a vida humana essa conservação de registros, vestígios ou experiências anteriores, pois é necessário dispor de grandes reservas de experiências humanas acumuladas para construirmos com esses elementos as imagens de que falamos.

A partir do que foi exposto podemos falar de outra função do psiquismo, que se apropria das informações retidas na memória, combina, reconstrói e cria. 


\section{ARTE E MEMÓRIA: DA CRIAÇÃO ARTÍSTICA À FORMAÇÃO DOS SENTIDOS ESTÉTICOS}

Toda a atividade humana que não se restringe à reprodução de fatos e impressões vividas, mas que cria novas imagens e ações, pertence a essa segunda função criadora ou combinatória. O cérebro não é apenas um órgão que se limita a conservar ou reproduzir nossas experiências passadas, mas é também um órgão combinatório, criador, capaz de reelaborar e criar, a partir de elementos das experiências passadas, novos princípios e abordagens (VIGOTSKI, 2014, p.3).

É aqui que já podemos estabelecer um paralelo entre a memória e a arte ou a potencialidade criadora do gênero humano. De uma realidade concreta extraem-se elementos que possibilitam a elaboração de obras de arte ou diversas formas de linguagens artísticas.

Segundo Vigotski (2014), a Psicologia chama de imaginação essa atividade criadora do cérebro e é considerada o fundamento de toda a atividade criadora humana e manifesta-se em todos os aspectos da vida cultural possibilitando além da criação cientifica e tecnológica a criação artística.

A imaginação é a intermediária entre percepção e pensamento. Assim, apesar de todo o conhecimento derivar, em última instância, de impressões sensoriais, não é a partir delas em estado bruto que o pensamento funciona, mas após tais impressões terem sido tratadas pela faculdade da imaginação ou absorvidas por elas (YATES, 2007).

Assim, é possível descrever de forma esquemática e sucinta o ciclo de desenvolvimento dos produtos da imaginação: os elementos da realidade são apropriados pelo homem, passam por um processo de reconstrução em seu pensamento e resultam nos produtos da imaginação. Por fim, ao serem materializados, retornam à realidade, mas trazendo consigo uma força ativa nova, capaz de transformar essa mesma realidade, fechando-se, assim, o ciclo da atividade criativa da imaginação humana.

É possível afirmar que tudo que é produzido e criado pelo homem, todo o universo cultural, distinto do universo natural, é produto da imaginação e criação humana. A capacidade de elaboração e construção a partir de elementos, de fazer novas combinações com elementos conhecidos, constitui o fundamento do processo criativo.

Aquilo que chamamos de criação é habitualmente apenas o ato do nascimento que ocorre como resultado de um prolongado processo interno de gestação. "É justamente a atividade criadora humana que faz do homem um ser que se projeta para o futuro, um ser que cria e modifica o seu presente" (VIGOTSKI, 2014, p.3).

As obras de arte podem exercer uma influência forte na consciência social das pessoas, pois a criação artística resulta da realidade e age sobre essa mesma realidade. Agem no 
mundo dos pensamentos, conceitos sentimentos do próprio homem. Com efeito, a imaginação e a criatividade são propriedades excepcionalmente humanas. E como tal, todo e qualquer ser humano é potencialmente criativo.

Diante do que foi discutido, infere-se que a memória e o acúmulo de conhecimentos possibilitam o desenvolvimento social e consequentemente o desenvolvimento da arte.

\begin{abstract}
Qualquer inventor, por mais genial que seja, é sempre o produto de seu ambiente e de sua época. A sua obra criativa partira dos níveis alcançados anteriormente e se apoiará nas possibilidades que existem também ao seu redor. É por isso que notamos uma sequência rigorosa na história do desenvolvimento da técnica e da ciência. Nenhuma invenção ou descoberta cientifica surge antes de se criarem as condições materiais e psicológicas necessárias para o seu aparecimento. A obra criativa representa um processo histórico contínuo, onde cada forma nova tem por base a precedente. (VIGOTSKI, 2014, p.32).
\end{abstract}

A arte é resultado das experiências humanas, da memória, da criatividade e da imaginação e o processo de produção artística envolve a apropriação da realidade humana através da compreensão desta realidade tanto por parte do artista, quanto do espectador.

Compreender os processos de apropriação para que se ofereçam oportunidades significativas de experiência estética, de caráter dialógico, aos indivíduos favorece sua ampliação de repertório e sentidos estéticos e contribui para formação humana.

\title{
4. A arte enquanto expressão de memória e sua especificidade na prática social
}

Cada sociedade produz sua arte com base nas possibilidades e necessidades de seu tempo e com base nas condições histórico-sociais objetivas que fazem desenvolver a criação artística, expressar e dar vazão a sua criatividade.

Isto quer dizer que arte e sociedade, longe de se acharem numa relação mútua de exterioridade ou indiferença, se buscam ou se rechaçam, se encontram ou se separam, mas jamais podem voltar completamente as costas uma para outra (VÁZQUEZ, 2010, p.107).

O autor citado ressalta que por ser a arte um fenômeno social, arte e sociedade não podem se ignorar e se influenciam mutuamente, por isso nenhuma arte foi impermeável à influência social, nem deixou, por sua vez, de influir na sociedade. 


\section{ARTE E MEMÓRIA: DA CRIAÇÃO ARTÍSTICA À FORMAÇÃO DOS SENTIDOS ESTÉTICOS}

$\mathrm{O}$ artista exprime em sua arte reflexos das práticas sociais e questões pertinentes à sua época histórica. À medida que a arte vai resistindo ao tempo resgata diversos elementos que permaneciam adormecidos e latentes e são trazidos para o presente. A arte acaba sendo uma ponte entre seu criador e os outros membros da sociedade. Por isso, pode-se afirmar que a arte tem o poder de sobrepor ao momento histórico e criar algo de duradouro e permanente. Vale dizer que produzir arte é também produzir memória.

Kosik (1976, p.128) ilustra isso com um exemplo bem interessante:

Uma catedral da Idade Média não é apenas expressão e imagem do mundo feudal, é ao mesmo tempo um elemento da estrutura daquele mundo. Não só reproduz artisticamente a realidade da Idade Média, mas ao mesmo tempo também a produz artisticamente.

Dessa forma, uma obra arquitetônica construída em outra época, seja a catedral medieval, ou um templo grego da Antiguidade, ou um palácio da renascença, exprimem a realidade e ao mesmo tempo criam a realidade. Não criam apenas a realidade dessas épocas respectivas, criam como perfeitas obras artísticas, uma realidade que sobrevive ao mundo histórico.

Por essa razão, Frederico (2013) conclui que a obra de arte é a memória da humanidade sendo apontada como um registro dos diversos momentos de sua trajetória. O seu caráter evocativo exige que o artista traga para a superfície do sensível os traços essenciais do real, distanciando-se assim, da imediatez e da mera transcrição da realidade objetiva.

Importante ressaltar que a arte não se constitui como uma cópia ou imitação do já existente. Cada obra de arte é reflexo da realidade ou de uma parcela do mundo real, e apesar de representar a essência do real, um reflexo do mundo, não vive no campo do pensamento e da ideologia que a inspirou, vive por si, como uma realidade própria e única. Com isso ela constitui-se num mundo em si mesmo.

Nessa perspectiva, Kosik (1976) reafirma que o homem criou a si mesmo não apenas como ser pensante, qualitativamente distinto dos animais de espécies superiores, mas também como único ser do universo, por nós conhecido, que é capaz de criar a realidade. E no momento em que ele reproduzir a realidade, ele cria uma nova realidade.

Por isso a obra de arte apresenta um duplo caráter em indissolúvel unidade: "é expressão da realidade, mas ao mesmo tempo cria a realidade, uma realidade que não existe fora da obra ou antes da obra, mas precisamente apenas na obra" (KOSIK, 1976, p.128).

\begin{tabular}{l|l} 
Revista RBBA & Revista Binacional Brasil Argentina
\end{tabular} 
$\mathrm{Na}$ composição da linguagem artística, procura-se destacar aquilo que é decisivo, essencial e marcante, e por isso impõe-se um processo de seleção e de acentuação dos traços e tendências mais relevantes da realidade a ser refletida. A arte ainda possibilita a vivência de contradições e conflitos das relações sociais já que, ao representar de maneira peculiar as forças sociais reais, carrega também o movimento das mediações da história do gênero humano.

Assim, a obra de arte é uma afirmação e uma evocação do representado pela humanidade que se transforma em uma produção cultural. Nessa capacidade de materializar suas forças essenciais, o homem produziu objetivações materiais e não-materiais que expressam sua essência e elevam a um grau superior a capacidade de expressão e afirmação do homem. Por isso é possível afirmar que a arte evidencia a capacidade criadora do homem e a sua capacidade de expressar o ser humano em toda sua plenitude.

Quando contemplamos o que o homem produziu de mais nobre e elevado, compreendemos que o ser humano tem a capacidade de produzir coisas melhores, visto que, os produtos da criação humana expressam do homem não apenas o que ele já é e o que já alcançou, mas também tudo o que ele ainda pode vir a ser. Nesse sentido, é possível afirmar que "os produtos não testemunham apenas a atual capacidade criativa do homem, mas também e em especial as suas infinitas potencialidades" (KOSIC, 1976, p. 122, 123).

A função essencial da arte é ampliar e enriquecer a realidade já humanizada pelo trabalho humano e com suas criações, o homem pode afirmar sua essência e se reconhecer no mundo objetivo criado por ele. A arte, como o reflexo de uma parcela do mundo humano, presentifica o que se produziu em épocas diferentes e espaços distintos imortalizando memórias. Por isso Duarte (2013, p.122) define "a arte como autoconsciência e memória da humanidade, do gênero humano".

Produzir arte também é possibilitar ao indivíduo o contato com as criações derivadas da atividade dos seres humanos. Assim, constata-se que as produções humanas se expressam na realidade concreta como objetivações tanto materiais como não-materiais. Através do processo de apropriação, o homem pode se autoconstruir ao longo da história e apropriar-se do que já foi vivido e conhecer um mundo que se constituiu no passado e continua se materializando no presente. 


\section{ARTE E MEMÓRIA: DA CRIAÇÃO ARTÍSTICA À FORMAÇÃO DOS SENTIDOS ESTÉTICOS}

Segundo Barroco e Superti (2014) a arte pode ser entendida como produto cultural, mediador entre o indivíduo e o gênero humano. Ou seja, a arte está intrinsecamente ligada à vida, às relações sociais de determinadas épocas.

Na visão ontológica de Lukács a arte é uma atividade que parte da vida cotidiana para em seguida, a ela retornar, produzindo nesse movimento reiterativo uma elevação na consciência sensível dos homens. Assim num primeiro momento, a arte nasce das necessidades impostas pelo cotidiano, e no momento seguinte retorna ao cotidiano dos seres humanos e com o objetivo de elevar a consciência dos sujeitos (FREDERICO, 2013).

Assim, é possível estabelecer um salto qualitativo da prática social partindo do senso comum e do cotidiano, para as formas superiores de consciência que superam esses limites. Nesse momento o indivíduo supera a sua singularidade e é posto em contato com o gênero humano.

A arte, nesse sentido, ajuda a transcender o homem e a superar a fragmentação produzida pela alienação de uma sociedade dividida em classe. Fischer (1973, p. 57) destaca que:

A arte pode elevar o homem de um estado de fragmentação a um estado de ser íntegro, total. A arte capacita o homem para compreender a realidade e o ajuda não só a suportá-lo como transforma-la, aumentando-lhe a determinação de torna-la mais humana e mais hospitaleira para a humanidade.

Após a fruição estética o homem volta a sua realidade com um novo olhar sobre o mundo. Volta a defrontar-se com um cotidiano fragmentado e imerso nas aparências enriquecido com novas experiências e reflexões. A atividade artística tem uma dimensão humana essencial e insubstituível, valorizando os sentidos como meio de afirmação do homem, dessa forma, é entendida não só como um modo de conhecer o mundo exterior, mas também como um fazer, uma práxis que permite ao homem afirmar-se ontologicamente.

Vigotski (1999) fala que a verdadeira natureza da arte sempre implica algo que transforma e assim se realiza a mais importante missão da arte: recolher da vida o seu material e produzir acima deste, algo que supera e que não está nas propriedades desse material. Ou seja, o material para o conteúdo e estilo artístico são apreendidos da realidade e trabalhados a partir dela.

Mas, para realmente captar o sentido da arte e poder não só apreciar uma obra como também se beneficiar de suas implicações no desenvolvimento do indivíduo devemos ter claro 
que os sentidos estéticos precisam estar apurados. Barroco e Superti (2014, p.25) destacam que "não basta que tenha acuidade visual, é preciso aprender a 'ler' o mundo", ou seja, para desfrutar da arte é necessária uma formação artística.

Assim, a sensibilidade estética é resultado de um longo e dialético processo histórico de humanização e formação dos cinco sentidos. Os sentidos são humanizados e, portanto, se desenvolvem e se constituem no decorrer do processo histórico-social.

A arte possibilita desenvolvermos uma forma própria de sentir e pensar. Nesse sentido, a percepção estética surge como elemento para identificar e constituir uma teia de significados entre o mundo do sujeito e o mundo da arte. $\mathrm{O}$ contato com a arte, adequadamente vivido e assimilado, tem algo a ver com o processo de desenvolvimento pessoal e da personalidade.

Por isso é necessário reafirmar a necessidade ontológica da arte para o desenvolvimento humano, pois as obras de arte são objetivações humanas essenciais, que tem o poder de mediação entre a história do gênero humano e o desenvolvimento individual.

\section{A arte e a formação de sentidos estéticos e desenvolvimento pessoal}

A sensibilidade estética é uma forma específica de sensibilidade humana, é uma conquista da humanidade que se dá a partir do refinamento das necessidades e dos sentidos humanos. Ao passo que o conhecimento inteligível trata de como o mundo é representado em nossa mente, através de signos racionais, o saber sensível trata de como o nosso corpo sabe o mundo, anteriormente ao pensamento, uma forma de saborear o mundo através de nossos sentidos.

A obra de arte é uma maneira elevada de expressão objetiva da subjetividade humana. Assim, a sensibilidade estética é resultado de um longo e dialético processo histórico de humanização e formação dos cinco sentidos. "O olho tornou-se um olho humano, no momento em que o seu objeto se transformou em objeto humano, social, criado pelo homem para o homem. Por consequência, os sentidos tornaram-se diretamente teóricos na sua prática" (MARX, 2006, p.142).

Os sentidos humanos pressupõem uma base biológica e natural, porém não se limitam a essa estrutura orgânica, isto é, deixam de ser tão somente biológicos e passam a ser 


\section{ARTE E MEMÓRIA: DA CRIAÇÃO ARTÍSTICA À FORMAÇÃO DOS SENTIDOS ESTÉTICOS}

essencialmente sociais. Os sentidos são humanizados e, portanto, se desenvolvem e se constituem no decorrer do processo histórico-social.

Uma das finalidades da arte é contribuir para o apuramento da sensibilidade e desenvolver a criatividade dos indivíduos. A gênese da criatividade é cultural, e desse modo, é inteiramente dependente da apropriação da cultura existente. Esta finalidade é uma dimensão amplamente reconhecida e considerada uma importante ferramenta de formação do indivíduo, ampliando as possibilidades cognitivas, afetivas e expressivas.

[...] o sentido musical do homem só é ancorado pela música. A mais bela música nada significa para o ouvido completamente não musical, não constitui nenhum objeto, porque o meu objeto só pode ser a ratificação de uma das minhas capacidades. Assim, só pode existir para mim na medida em que a minha capacidade existe para ele como habilidade subjetiva, porque para mim o significado de um objeto só vai até onde chega o seu sentido (só tem significado para um sentido que lhe corresponde). Consequentemente, os sentidos do homem social são diferentes dos do homem não social. Só por meio da riqueza objetivamente desenvolvida do ser humano é que em parte se cultiva e em parte se cria a riqueza da sensibilidade subjetiva humana (o ouvido musical, o olho para a beleza das formas), em resumo, os sentidos capazes de satisfação humana e que se confirmam como capacidades humanas (MARX, 2006, p.143).

Tal afirmativa deixa evidente que a sensibilidade humana, como por exemplo, o ouvido musical ou o olho que aprecia a beleza de uma obra de arte, não são sentidos formados tão somente por propriedades biológicas e herdados geneticamente, mas dependem de condições sócio históricas e da educação. A subjetividade que se objetiva e é apropriada por outrem, se enriquece e se desenvolve historicamente. Destarte, é preciso criar na subjetividade de cada um aquilo que já foi criado pela humanidade.

A percepção estética surge como elemento para identificar e constituir uma teia de significados entre o mundo do sujeito e o mundo da arte. Leontiev (2000) afirma que o contato com a arte, adequadamente vivido e assimilado, tem algo a ver com o processo de desenvolvimento pessoal e da personalidade. Nesse sentido, "a educação estética é a capacidade de perceber e entender a arte e a beleza em geral" (LEONTIEV, 2000, p.128).

A percepção estética é uma atividade interna complexa, em que o primeiro contato visual com uma obra, o ato de ouvir uma sinfonia, ou contemplar uma encenação de dança ou teatro é apenas o primeiro passo, e será recebida pelos indivíduos de formas diversas. 
Nem todos os receptores conseguem que todas as obras de arte lhes falem. É necessária uma chave especial em cada caso, para cada gênero artístico, um conjunto de atributos que permitem a sua devida percepção. Leontiev (2000, p.33) atribuiu a esta chave nome de competência estética, que implica:

A capacidade do leitor, espectador, ouvinte para extrair conteúdos de significado de diferentes níveis de profundidade da textura estética de uma produção artística esta variável reflete o nível geral do desenvolvimento estético de uma pessoa, a sua experiência de encontros com a arte.

Existem alguns fatores essenciais que irão determinar de forma crucial o processo e os resultados provenientes da mediação entre indivíduo e a arte. A competência estética é um desses fatores. Dois outros fatores são o mundo interior do indivíduo, ou seja, a estrutura de sentido da personalidade e as necessidades dominantes que definem substancialmente a opção individual pelos gêneros artísticos existentes.

Com base nas obras teóricas e experimentais existentes, Leontiev (2000, p. 133) destaca, pelo menos, três aspectos interligados da competência estética.

O primeiro aspecto é a complexidade cognitiva da visão do mundo que um indivíduo tem a capacidade pessoal de compreender a ambiguidade e de ver as possibilidades que as coisas têm de mudar, de ser diferentes. $\mathrm{O}$ segundo aspecto é o domínio que uma pessoa tem das linguagens especiais de diferentes tipos, gêneros e estilos de arte, que requer um conjunto de códigos culturais (lotman), que torna possível decodificar a informação contida no texto artístico de modo a traduzir a estrutura de sinais de uma produção artística na língua materna das emoções e significados humanos. O terceiro aspecto da competência estética, oriundo das características de atividade da percepção artística, é o grau de mestria das competências e aptidões operacionais que define a capacidade pessoal para desempenhar a atividade de objetivação de textos relevante para um determinado texto.

Percebe-se com isso que a competência estética não é algo simples e inerente aos homens. É resultado de um longo processo de apropriação das objetivações humanas e da superação das fragmentações numa perspectiva que almeja a totalidade humana. É preciso que os sentidos sejam desenvolvidos e humanizados gradativamente. É preciso de bases sociais concretas para desenvolver o olhar critico sobre os reflexos culturais de um determinado modo de produção, assim como ações condizentes com este olhar. 


\section{ARTE E MEMÓRIA: DA CRIAÇÃO ARTÍSTICA À FORMAÇÃO DOS SENTIDOS ESTÉTICOS}

Por isso, é importante retomar Leontiev (2000) e citar aqui algumas funções psicológicas que a arte assume de acordo com o principal efeito que é suposto resultar do encontro com os indivíduos: recreação, socialização e desenvolvimento pessoal.

A recreação é necessária a todos os seres humanos e está associada às necessidades psicológicas básicas. A maior parte dos tipos, gêneros e estilos de arte contém uma componente recreativa mais ou menos evidente, porque a arte sempre pertenceu à esfera da livre atividade, independentemente de quaisquer deveres sociais ou profissionais.

Quem cumpre essa função recreativa na sociedade é a arte proveniente da indústria do entretenimento. A cultura de massa de hoje transforma os objetos de arte em mercadorias com um elevado potencial lucrativo, excluindo todos os outros gêneros de esforços mentais.

A função recreativa da arte é muito mais procurada do que qualquer outro tipo e está disponível para todos. "A abordagem da arte como um instrumento recreativo não requer, pois, qualquer educação, porque o mundo dos objetos quase-arte recreativos adapta-se perfeitamente ao nível mais baixo (zero) de educação e de competência estética" (LEONTIEV, 2000, p.143).

As características do público para esse tipo de arte são: a prontidão para reconhecer o que já é bem conhecido e a rejeição do novo, o desinteresse pela arte que exija qualquer atividade mental mais elaborado, ou seja, a procura do prazer sem esforço. Além disso, é comum reproduzir o discurso, as opiniões e juízos que as massas partilham.

O segundo tipo de arte trazido por Leontiev (2000) é a arte de orientação socializante. Esse tipo de arte fornece informação sobre o mundo, sobre os valores culturais, padrões de comportamento e modelos de identidade pessoal. É um tipo de arte que transita entre a cultura de massas e a arte mais erudita.

É um tipo de arte que atendem ao divertimento cumprindo a função da recreação, mas que conseguem transmitir algum tipo de significado. Promovem a socialização e à medida que se aprende, aproxima-se de determinada cultura.

Esta função não é específica da arte. Percebe-se que a maior parte das pessoas prefere aprender de outras fontes, os jornais, por exemplo, são mais eficazes para atingir este objetivo. A educação relevante para esta função é muito mais a educação geral tradicional que a educação estética.

Já a arte orientada para o desenvolvimento pessoal, pelo contrário, pressupõe e exige frequentemente um elevado nível de competência estética, confere novos significados e novas

\begin{tabular}{l|l} 
Revista RBBA & Revista Binacional Brasil Argentina
\end{tabular} 
maneiras de ver e de avaliar a realidade. Segundo Leontiev (2000) é aqui que reside o objetivo mais importante da educação estética.

No entanto, para nos tornarmos conscientes do verdadeiro significado da arte, temos primeiro de perceber as diferenças entre os efeitos da arte para o desenvolvimento pessoal e da quase-arte representada pela cultura comercial de massas. A educação visa o desenvolvimento pessoal e luta pela dimensão humana nos seres humanos.

É essa função artística que devemos entender e discutir para a formação do indivíduo. Devemos buscar tocar no âmago da verdadeira arte que é o sentido pessoal. Leontiev (2000, p.132) declara que:

O que deveríamos ensinar é a atitude dialógica para com a arte, a capacidade não apenas de ver o mundo significativo que transcende os meios expressivos, mas também de nos relacionarmos pessoalmente com este mundo, de nos abrirmos a ele e de nos enriquecermos pessoalmente com este mundo, de nos abrirmos a ele e de nos enriquecermos com os significados aí descobertos.

Por isso que a interação dialógica com uma obra de arte nos dá a oportunidade de ampliar nossa visão de mundo enriquecendo as experiências da vida real. O contato com a arte possibilita viver várias vidas em vez de uma, por isso nos obriga a lutar para além da nossa vida em direção a tudo que a transcende, buscando a totalidade das relações e objetivações humanas.

Uma obra de arte é uma janela para o mundo do artista, que está aberta apenas para uma visão de um ponto de vista único, ou seja, o do autor, por isso, para a obra de arte se revelar, uma pessoa tem de renunciar, temporariamente, à sua posição pessoal, que é uma posição parcial no mundo, assim como renunciar o seu ponto de vista exclusivo e aceitar a posição do artista.

Para conseguir penetrar para além do texto, para além do quadro e conseguir entrar em contato com os significados vivos da obra de arte, devemos aprender a olhar o mundo através dos olhos do artista. Por essa razão que Leontiev (2000) afirma que assumir uma atitude estética é essencialmente adotar uma atitude de diálogo, a atitude de uma aceitação imparcial e sem vínculos emocionais. 


\section{ARTE E MEMÓRIA: DA CRIAÇÃO ARTÍSTICA À FORMAÇÃO DOS SENTIDOS ESTÉTICOS}

O paradoxo da percepção estética reside no fato de que só renunciando à percepção pessoal de uma obra de arte através do prisma dos próprios significados pessoais, é que o observador consegue compreender a obra em toda plenitude do seu significado e, nesta interação, enriquecer o seu próprio mundo interior. O primeiro passo neste processo - ver uma imagem do mundo de determinada pessoa por detrás da representação do mundo e assumir, em relação a ela, uma atitude empática de diálogo - permite ir mais longe, ou seja, da imagem do mundo para o mundo em si. Nesta fase, os significados contidos na obra interagem com as estruturas de sentido da personalidade do receptor. Este processo conduz à absorção dos nossos conteúdos e aspectos nas estruturas de significado individuais, se não houver contradição entre elas, ou no efeito da catarse, se houver contradição entre os significados contidos na obra de arte e os que são inerentes à percepção do mundo dos indivíduos. Isto promove o colapso dos estereótipos de sentido pessoais, acrescido de um relevo enriquecido de uma percepção do mundo e do desenvolvimento da capacidade de ver objetos e eventos simultaneamente de muitos pontos de vista, em muitos contextos e significados potenciais (LEONTIEV, 2000, p130 e 131).

Uma verdadeira obra de arte tem um conteúdo objetivo profundo, independentemente das eventuais impressões do receptor. $\mathrm{O}$ contato com a arte, adequadamente vivido e assimilado contribui de forma significativa com o processo mais íntimo do desenvolvimento do psiquismo. Uma vez que a imagem artística complexa produz inevitavelmente variações individuais na sua compreensão e avaliação da arte.

Baseado em Vigotski (1999) é possível afirmar que um aspecto da reação estética é de que ela não é apenas uma descarga no vazio, um tiro de festim, mas uma reação à obra de arte de um estimulante novo e fortíssimo para posteriores atitudes. A arte exige resposta, motiva certos atos e atitudes. A arte é antes uma organização do nosso comportamento visando o futuro, uma orientação para o futuro, uma exigência que talvez nunca venha a concretizar-se, mas que nos leva a aspirar acima da nossa vida que está por trás dela.

As obras de arte não têm uma função social definida tão somente pela busca de prazer, vão muito além disto; as objetivações artísticas estão vinculadas, de modo geral, ao processo de desenvolvimento do gênero humano, e de maneira particular, ao desenvolvimento do indivíduo singular. É algo que transcende a vida cotidiana.

Vigotski (1999, p.307, 308) afirma que:

A arte está para a vida como o vinho para a uva disse um pensador, e estava coberto de razão, ao indicar assim que a arte recolhe da vida o seu material mas produz acima desse material algo que ainda não está nas propriedades desse material. 
A partir dessa estreita relação da arte com a vida, podemos concebê-la como uma produção elevada da atividade humana. A arte desencadeia uma transformação nas emoções e que, tomando o psiquismo como uma unidade, podemos concluir que a arte transforma toda a estrutura psíquica do indivíduo.

A arte, como objetivação resultado do trabalho humano, intervém decisivamente na formação das propriedades humanas. E um traço marcante e decisivo nesse processo é a assimilação dos resultados da experiência de toda a humanidade. As ações e habilidades humanas resultam das assimilações da experiência das gerações passadas acumuladas em forma de conhecimentos, das apropriações do legado construído histórico-socialmente.

\section{6. Últimas considerações}

A partir da psicologia histórico-cultural, mais precisamente nas obras de Vigotski, Luria e Leontiev foi possível identificar a concepção de memória, não só como função psíquica, mas também como fenômeno histórico social.

A partir de então, analisamos como as experiências humanas e a memória se relacionam a outras funções psíquicas e servem de base para a imaginação e a criatividade no processo de criação artística.

O que permitiu mais uma vez correlacionar arte e memória no contexto da prática social. A criação artística parte de experiências registradas na memória. Essas experiências, uma vez transformadas em arte, permitem mobilizar outras funções como sensação, percepção e emoção, que contribuem significativamente para a formação dos indivíduos.

A arte é resultado de um longo processo criativo que parte da memória e das experiências humanas e está destinada a evocar a vida de homens e mulheres como obra coletiva da humanidade. A arte tem a característica de possibilitar ao homem o contato com as diferentes esferas da sua produção, se reconhecendo como produtor e criação, ele se reencontra com as objetivações humanas através da arte. Podemos concluir que a obra de arte é a memória do gênero humano. A arte, nesse sentido, ajuda o homem a transcender e a superar a fragmentação produzida pela alienação de uma sociedade dividida em classes.

O desenvolvimento do indivíduo é resultado da síntese de inúmeras relações sociais e precisa ser concebido como um processo situado no interior de outro, o do desenvolvimento 


\section{ARTE E MEMÓRIA: DA CRIAÇÃo ARTÍSTICA À FORMAÇÃo DOS SENTIDOS ESTÉTICOS}

histórico do ser humano como um ser social. A partir desses pressupostos entendemos também que a relação entre os processos de objetivação e apropriação constitui a dinâmica fundamental do processo de formação do indivíduo em suas máximas possibilidades, como um ser histórico e social, pelo qual o ser humano se autoconstrói ao longo da história.

\section{Referências}

BARROCO, S. M. S; SUPERTI, T. Vigotski e o estudo da psicologia da arte: contribuições para o desenvolvimento humano. Psicologia \& Sociedade, 26(1), 22-31, 2014.

DUARTE, N. A individualidade para si: contribuição a uma teoria histórico-crítica da formação do indivíduo. 3ed. Campinas: Autores Associados, 2013.

FISCHER, E. A necessidade da arte. Rio de Janeiro: Zahar Editores, 1973.

FREDERICO, C. A arte no mundo dos homens: o itinerário de Lukács. São Paulo: Expressão Popular, 2013.

KOSIK, K. A dialética do concreto, $2^{\text {a }}$ ed., São Paulo: Paz e Terra, 1976.

LEONTIEV, A. Funções da arte e Educação Estética. In: FRÓIS, J.P Educação Estética e Artística: abordagens transdisciplinares. Org. FRÓIS J. P. Lisboa: Fundação Calouste Gulbenkian, 2000.

LURIA, A. R. Curso de Psicologia Geral: Atenção e Memória. 2. Ed. Rio de Janeiro: Civilização Brasileira, 3v, 1999.

MARTINS, L. M. O desenvolvimento do Psiquismo e a Educação Escolar: Contribuições à luz da psicologia histórico-cultural e da pedagogia histórico-crítica. Campinas, SP: Autores Associados, 2013.

MARX, K. Manuscritos econômicos e Filosóficos. São Paulo: Editora Martin Claret, 2006.

SACCOMANI, M. C. da S. A criatividade na arte e na educação escolar: uma contribuição à pedagogia histórico-crítica à luz de Georg Lukács e Lev Vigotski, 2014. 186 f. Dissertação de Mestrado em Educação Escolar - Universidade Estadual Paulista "Julio de Mesquita Filho", Faculdade de Ciências e Letras: Araraquara.

VÁZQUEZ, A. S. As ideias estéticas de Marx. São Paulo: Expressão Popular, 2010.

VIGOTSKI, L. S. Psicologia da arte. São Paulo: Martins Fontes, 1999.

VIGOTSKI, L. S. Imaginação e criatividade na infância. São Paulo: WMF Martins Fontes, 2014. 
VIGOTSKI, L.S; Luria, A. R Estudos sobre a história do comportamento: símios, homem primitivo e criança. Porto Alegre: Artes médicas, 1996.

YATES, F. A. A arte da memória. Campinas, SP: Editora UNICAMP, 2007.

\section{Sobre a autora}

Isis Conrado Haun. Mestra em Memória: Linguagem e Sociedade pela Universidade Estadual do Sudoeste da Bahia - UESB e Doutoranda do Programa de PósGraduação em Memória: Linguagem e Sociedade, da mesma universidade. Professora da rede estadual de ensino (SEC-BA). É vinculada ao grupo de pesquisa Museu Pedagógico: Estudos Marxistas em Memória e História da Educação e Cultura (UESB). Endereço Eletrônico: isisconrado@yahoo.com.br 